\title{
INTERNAL REPORTING ON PROCESS OPTIMIZATION MEASURES: COMBINATION OF ECONOMIC AND ENVIRONMENTAL ASPECTS
}

\author{
UDC 657.6
}

\author{
Rudolf Grünbichler ${ }^{1}$, Barbara Petschacher ${ }^{2,3}$, René Kollmann ${ }^{4}$, \\ Alexander Passer ${ }^{4}$, Stefan Grbenic ${ }^{1}$ \\ ${ }^{1}$ Graz University of Technology, \\ Institute of Business Economics and Industrial Sociology, Graz, Austria \\ ${ }^{2}$ Austrian Centre of Industrial Biotechnology, Graz, Austria \\ ${ }^{3}$ Graz University of Technology, \\ Institute of Biotechnology and Biochemical Engineering, NAWI Graz, Graz, Austria \\ ${ }^{4}$ Graz University of Technology, Institute of Technology and Testing of Construction \\ Materials, Working Group Sustainable Construction, Graz, Austria
}

\begin{tabular}{|c|c|c|}
\hline \multirow[t]{5}{*}{ ORCID iD: } & Rudolf Grünbichler & (1) https://orcid.org/0000-0002-5872-5771 \\
\hline & Barbara Petschacher & (1) https://orcid.org/0000-0003-2472-484X \\
\hline & René Kollmann & (1) https://orcid.org/0000-0003-1747-6729 \\
\hline & Alexander Passer & (1) https://orcid.org/0000-0001-8773-8507 \\
\hline & Stefan Grbenic & (1) https://orcid.org/0000-0003-1245-5929 \\
\hline
\end{tabular}

\begin{abstract}
Optimizing the cost situation is part of everyday business in a company. The research field of controlling has developed many instruments and methods for calculating potential savings and communicating them to the decision-makers. In the future, in order for companies to operate more sustainably it is necessary to weigh up optimization measures from an economic and environmental point of view. This paper proposes to supplement controlling reports with a matrix opposing economic and environmental impacts by individual optimization measures. This reporting method should assist decision-makers in the selection of optimization measures, taking into account economic and environmental aspects. LCA and LCC based evaluation of a biotechnological process step for glycoside production served as a case study. An example for impact presentation of switching to a sustainable electricity mix is shown.
\end{abstract}

Received June 22, 2021 / Revised November 25, 2021 / Accepted November 29, 2021

Corresponding author: Rudolf Grünbichler

Graz University of Technology, Institute of Business Economics and Industrial Sociology, Kopernikusgasse 24/II, 8010 Graz, Austria |E-mail: rudolf.gruenbichler@tugraz.at

ㄷ 2021 by University of Niš, Serbia | Creative Commons Licence: CC BY-NC-ND 
Key words: reporting, process improvement, LCA, LCC, LCA/LCC combination, economic and environmental performance, sustainability, CARBAFIN

JEL Classification: D24, L65, Q51

\section{INTRODUCTION}

The controlling department supports the management and prepares decision-making basis for the improvement of the company. One focus is on the optimization of costs. Potential cost savings are identified and strategies for implementation are proposed. This also includes the optimization of processes in order to raise cost saving potentials. In the last two decades, and in view of global warming, there has been an increasing focus on environmental concerns and the reduction of pollutant emissions (Keoleian \& Menerey 2012; Anastas \& Eghbali 2010). These aspects need reflection in parallel to cost aspects in environmentally conscious manufacturing and future decision-making support by controlling departments.

Life cycle costing (LCC) is an instrument with which the total costs of a product can be recorded, evaluated and optimised over its entire life cycle. This makes it possible to identify potential cost savings even before a product is launched on the market and while it is still in the product development phase. On the other hand, there is the instrument of environmental life cycle assessment (LCA), which enables a systematic analysis of the environmental impacts of products throughout their entire life cycle. The greatest opportunity for reducing the environmental impact of a new product in intervening in the life cycle of a product as early as the design phase (Fitzgerald et al., 2005).

The practical problem that arises here is that economic and environmental optimization are usually regarded as conflicting objectives of a company (e.g. Söllner 1998). In order to avoid one-sided cost optimization at the expense of the environment, essential agreements on climate protection have already been reached, among others, with the regulations of the Kyoto Protocol and then the successor agreement, the Paris Agreement. These agreements emphasize that companies from industrialized countries in particular must make their contribution to achieving the climate goals. As stated by Dascalu, Caraiani \& Lungu (2008), the design of environmental policy thus has an influence on the costs of companies for climate protection. Increased efforts in implementing environmental protection measures elevate the need for evaluation of possible process optimizations from economic and environmental perspective. Often efforts in environmental protection are expected to rise costs. However, process optimization measures taken based on environmental assessment results can as well lead to cost reductions, a fact which might not be anchored well in managers' mindsets yet.

The research question for this paper is derived from this conflicting situation: How can suggestions for improvement be presented to management so that they can make a decision to implement them taking into account both the economic and environmental situation? We here demonstrate an easy-to-understand communication method for effects of suggested improvements taking into account results from LCC and LCA.

The method is showcased on first results from LCC and LCA evaluation of optimization of a biotechnological process for glycoside production. The process optimization and evaluation was done in the framework of the EU H2020 financed CARBAFIN project.

This paper consists of five sections, with this section being the first. The second section reviews literature described approaches taken to combine life cycle costing (LCC) 
and life cycle assessment (LCA). The third section presents the research methodology of this study including the approach to economic and environmental analysis. Combined LCC and LCA result presentation is shown for an application example in the fourth section. The fifth section contains the conclusion with the main results, limitations of this study and suggestions for further research.

\section{APPROACHES FOR LCA AND LCC COMBINATION}

In LCA the environmental impact of products or processes over their life cycle is evaluated. LCA methodology is described in standards ISO 14040:2006 and ISO 14044:2006 and together with LCC and sLCA as part of the UNEP/SETAC approach towards a life cycle sustainability assessment (Valdivia et al. 2013). LCA is now widely applied in many sectors (e.g. De Soete et al. 2017; Obrecht et al. 2020; Moretti et. al. 2021; Kumar \& Verma 2021). Many approaches to LCAs have been established, as Fazeni, Lindorfer \& Prammer (2014) describe in their paper. However, they explicitly emphasize that the connection to LCC is only very sporadic and that there is a need for further research to combine these approaches, which is still valid today. For example, Ouattara et al. (2012) propose in their paper combined mathematical, economic, and environmental optimization strategies for process design. However, this method might be considered as too complex for everyday application in controlling reports.

Approaches to optimizing technical, environmental and economic aspects have already been described for individual areas. Ribeiro et al. (2008) use a methodology to compare a set of candidate materials and identify the "best material domains" by aggregating the three dimensions (technical, economic and environmental). These "best material domains" are presented in a diagram. This enables a global comparison of candidate materials to support a decision on the selection of the best material according to different business scenarios and corporate strategies. The focus of their work is on the selection of the best materials, taking into account these three dimensions.

More recent literature shows that in some cases optimization is one-sided with a focus on cost optimization and that a more comprehensive optimization of all areas is required (e.g. Patel, Zhang \& Kumar 2015). Current literature demonstrates that a comprehensive approach to process optimization from a technical, environmental and economic perspective is attracting more and more attention (Vaskan, Pachon \& Gnansounou 2017; Cavaignac, Ferreira \& Guardani 2021). Ögmundarson et al. (2020) propose a framework for the optimisation of biochemical processes, which includes the environmental and economic components in the evaluation. Their framework uses a set of quantitative indicators from LCA and techno-economic assessment (TEA). As a result of the preceding LCA analyses, the total sustainability costs per given functional unit are calculated. This value reflects the human health costs, ecosystem quality costs and natural resources costs and can finally be combined with the techno-economic costs to a single monetary output value. This single output value for a combined LCA and LCC analysis contributes to the above mentioned easy-to-understand communication. However, the authors acknowledge the challenges related to subjective value choices in the monetization of human and environmental health which involve moral questions. For a broad overview on integrating life cycle assessment and life cycle cost we refer to Franca et al. (2021).

Pesonen \& Horn (2013) name two main issues in the context of LCA from a management perspective that require further work: (1) approaches to speed up the resource-intensive 
inventory and assessment process, and (2) easy-to-understand communication of the results. In their study, they aim to contribute to these needs for faster and cost-effective ways to develop strategies that incorporate the life cycle perspective. Luthin, Backes \& Traverso (2021) also address the combined assessment of LCC and LCA in a recent study developed at the same time and simultaneously to this paper. Visual solutions for comparison of LCA and LCC results for complete production scenarios for aluminum in three different countries were presented.

\section{METHODOLOGY AND RESEARCH QUESTION}

The main purpose of this paper is suggesting a communication method for expected effects of process improvement proposals, taking into account economic and environmental aspects. The focus is on internal reporting to the management in order to assist a wellfounded decision on process improvements to be carried out. We focus on a suggestion for reporting of single improvement proposals taking into account results from prospective LCC and LCA. Since this is an optimization taking into account two dimensions, the bundle of individual measures can be represented in a diagram as a portfolio (matrix) with two axes. The portfolio theory has long been known (Markowitz 1952) and has already been applied in many business management issues (e.g. Baum, Coenenberg \& Günther 2006). The application of such matrices has already been taken up in the literature, but mostly in connection with specific business areas (e.g. Simoes et al 2016). As a general basis for process improvement proposals, a 4-quadrant model is here suggested that shows economic and environmental implications for the implementation of improvement measures and can be integrated into controlling reports. While costs anyway are represented by a single monetary value, we use the sustainable process index (SPI) as aggregated single output value for environmental burdens. Further details are given below. The proposed reporting method serves as a guide for strategy recommendations, as it clearly shows which proposed measures are associated with savings in both economic and environmental terms, which have negative impacts in both categories, and which lead to a trade-off between environmental and economic aspects and therefore require special consideration. On the basis of a technical improvement proposal catalogue, the effects on the economic and environmental side can thus be easily examined.

\subsection{Case study: Biocatalytic process for glycoside production}

The here suggested combined LCA and LCC result presentation is show-cased on a unit operation "biocatalytic synthesis of a glycoside" of an existing biotechnological process. This approach emphasizes the value of the suggested method for controlling reports based on realistic numbers on the effect of electricity supply switch. While not relevant for showcasing the suggested presentation method, for completeness a short description of the process is given here. The economic and environmental process evaluation is a first partial result of the research project CARBAFIN, which is funded by the European Union H2020 program. CARBAFIN develops biocatalytic processes for the production of glycosides. Glycosides are chemicals that contain at least one sugar moiety attached by a glycosidic bond to a core molecule. A model product is 2-glucosylglycerol which finds application as moisturizer in cosmetic industries. Main raw materials for the biocatalytic synthesis are sucrose and glycerol. With the help of the biocatalyst the glucose subunit from sucrose is transferred to glycerol. Fructose is a side product. The project aims 
to evaluate implementation on an industrial scale. The approach in this multidisciplinary research project is designed in the sense of a single-case study (Yin 2011; Yin 2017) with the inclusion of several methods. The processes are optimized technologically as well as from an economic and environmental point of view. A full fletched combined LCA and LCC study on the CARBAFIN processes is intended to be published later.

\subsection{Economic approach to process optimization}

The procedure for creating a life cycle model was based on the standard literature on life cycle costing (e.g. Coenenberg et al. 2016; Ewert \& Wagenhofer 2014). First of all, a distinction is made between the data gathering phase and the data processing phase. The evaluation of the case study process was done in a cradle to gate setting. Based on the process steps specified by the company, all cost types were first identified with the quantity inputs. In addition, the prices per unit of measure were collected. The data collection represented an elaborate process. First, the rough data was collected with the help of a questionnaire sent to the company. Missing data and inconsistencies were clarified and followed up in telephone calls and internet research.

In parallel, a life cycle cost model (e.g. Zehbold 1996) was developed in Microsoft Excel. A life cycle of 10 years was defined in consultation with the cooperation partner. The reason for the chosen timeframe is that after this period of time the plants have to be replaced. The collected data was then incorporated into the model. Operational expenditures were planned in detail for the first year. Since the annual production volume is assumed to remain constant for the life cycle, there is only an inflation due to inflation adjustments, which was considered separately for each cost type. In the case of capital expenditures, replacement investments were planned for individual parts of the production plant.

The model data can be used to determine various information for optimization proposals. Hotspot analysis is used to reveal the process steps that are expensive in the process. Furthermore, those cost types were identified which account for the highest proportionate costs over the entire process. This information is used to make suggestions for optimizing the use of raw materials and the process itself. For each feasible optimization measure, the costs before optimization were compared with the costs after optimization to determine a percentage cost difference on the total costs per step or process.

\subsection{Environmental approach to process optimization}

LCA is now a widely used methodology for the environmental sustainability evaluation for a product, process or service. LCA is an analytical tool to provide solid, comprehensive and quantifiable information about the environmental performance of products, processes or human activity throughout its entire life cycle (Audsley et al. 1997). The methodology is standardized by the International Standardisation Organisation (ISO) in the 14040 and 14044 series of ISO standards (ISO 2006) providing a general framework for conducting a life cycle assessment. An LCA is subdivided in four main phases as presented in Figure 1. Goal and scope definition; Life Cycle Inventory Analysis; Life Cycle Impact Assessment; and Life Cycle Interpretation. Results will depend on the selected evaluation methodology, data quality as well as the defined system boundaries. Although no environmental evaluation is telling the "ultimate truth", LCA can point out relevant environmental aspects and is regarded a useful tool for decision making. 


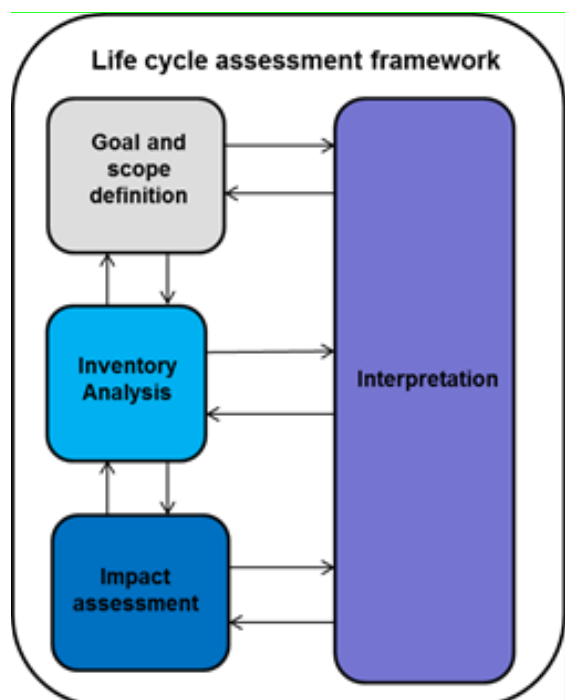

Fig. 1 Performing LCA is standardized Source: ISO- Norm 14040 and 14044

In short, for the case study process the main phases were handled as follows:

\section{Goal and scope definition}

The goal of the study was internal evaluation of process options and development in the project. The case study evaluation was performed on a biotechnical process as implemented in a German manufacturing plant. The here shown example of change in electricity from conventional mix to a sustainable mix is only one first obvious option for improvement, in later project phases more options will be identified. The LCA was done in a cradle to gate manner. Functional unit was the yearly mass of glycoside product which is sold to B2B customers.

\section{Life Cycle Inventory (LCI)}

Inventory analysis included primary data from the manufacturer as well as secondary data for raw materials and energy provision (Ecoinvent database). Energy demand in the plant was partly calculated based on physical equations. The inventory items used are identical to the ones used for LCC except that no impact by personnel is taken into account while LCC data includes wages. The below shown results refer to the inventory of one single process unit operation, the biocatalytic synthesis step (fermentation of the biocatalyst is not included in this step).

\section{Life Cycle Impact Assessment methodology - Sustainable process index (SPI)}

As LCIA methodology the sustainable process index (SPI) method was used. The SPI calculates the environmental footprint as the cumulative area which is necessary to implant the entire life cycle of an industrial process, product or service in the biosphere in a strongly sustainable way. The SPI takes into account all relevant environmental impacts including all resulting emissions for the upstream chain to the end of life. Material and energy flows that are taken from and released to the ecosphere are compared with the natural flows (Narodoslawsky \& Krotscheck 1995; Narodoslawsky \& Stoeglehner 2010; Shahzad et al. 
2014). The total area $A_{\text {tot }}$ for embedding of human activities sustainably into the ecosphere is calculated. Areas comprising the overall footprint are shown in detail in Figure 2.

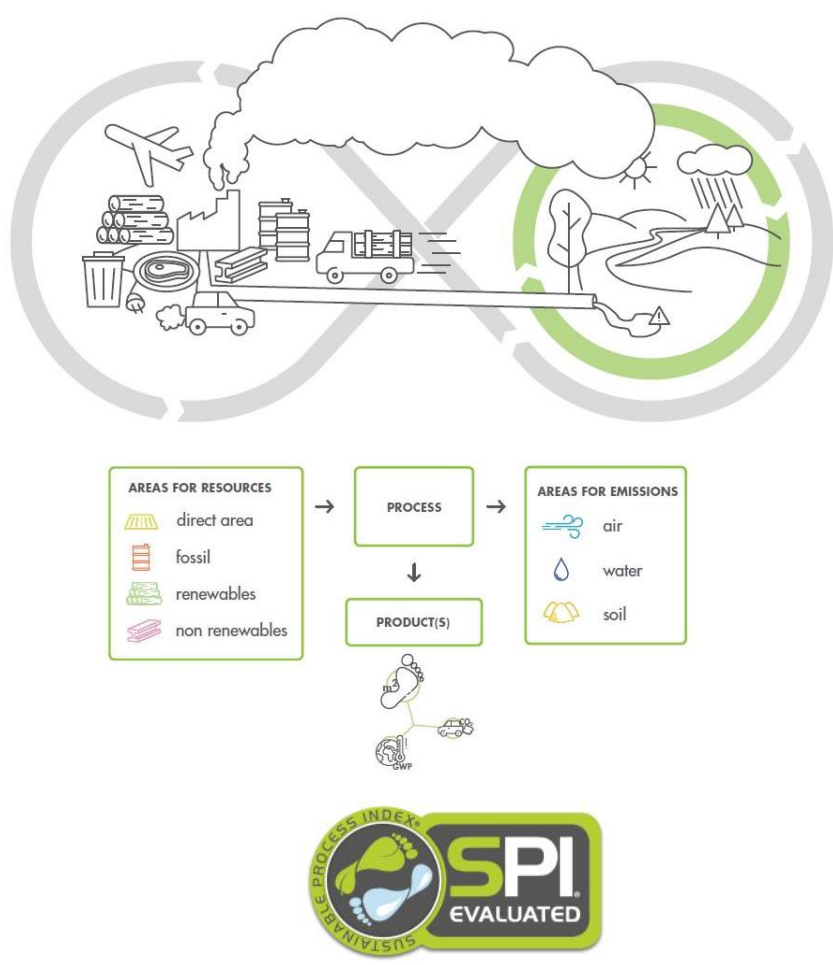

Fig. 2 Anthropogenic- vs. natural lifecycles - SPI calculation, material and energy flows of a process. "The more humans exceed these natural renewal rates, the larger the environmental footprint."

Source: adapted from SPIonWeb, CSTRATECO OG (SPIonWeb 2013-2019; STRATECO 2021)

The SPI method is available for application free of charge by the SPIonWeb software tool and methodology is described there in detail as well (http://spionweb.tugraz.at/ and https://spionweb.tugraz.at/en/spi). With this tool product life cycles are described as process chains that can be updated and further developed. As results the user gets the SPI footprint of a product or process as cumulated square meter number. $\mathrm{CO}_{2}$ life cycle emissions and GWP of the whole life cycle (Neugebauer et al. 2015) can be calculated as well but were not used in this study. In comparison to other LCIA methods which evaluate environmental impacts in several more impact categories, the SPI delivers with the cumulative area of the footprint a single aggregated impact value which allows graphical representation together with costs in a single two-dimensional plot.

\section{Interpretation}

For interpretation of the results a visualisation in combination with LCC results is used in order to guide decision on whether to implement a suggested process change or not. While in the here presented case of electricity supply change the result is clear, in 
other cases changes in and trade-offs between environmental and economic impact will be more subtle. A sensitivity analysis of single parameters and a careful quality assessment of used data then is essential.

\section{RESULTS}

In order to be able to communicate the effects of individual improvement measures to management, the economic and environmental impact reduction potentials or increases are presented in a matrix as a percentage of the total costs or the total footprint before the improvement. When the entire bundle of measures is presented, the result is a portfolio of measures that provides the decision maker with information on which measures have which economic and environmental impacts.

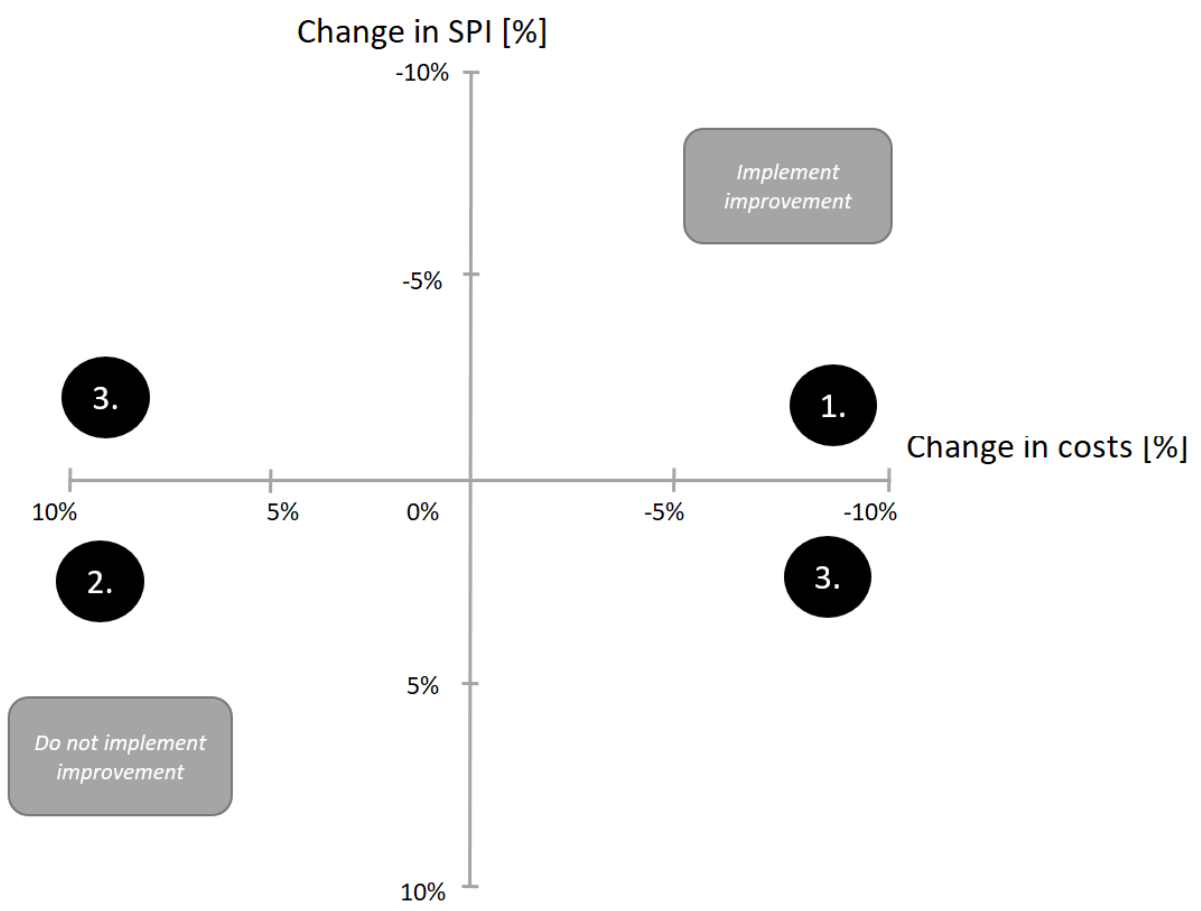

Fig. 3 Optimization matrix with implications for the implementation of process improvements

Figure 3 shows a matrix with the implications for implementing improvement suggestions. The origin with $0 \%$ describes the original costs and emissions before any process improvement. In the following, improvement measures are analyzed. These can be technical process improvements or changes in raw material or energy supply that have an impact on costs and the environmental footprint. In an iterative process, the feasibility is checked and the impact on the costs and the footprint is presented. The processes shown in the diagram are schematic. Cost or environmental footprint can increase or decrease compared to the reference process. 
The individual potential process improvements are entered in the chart. Four directions emerge: Costs can rise or fall and emissions can rise or fall. There are therefore two clear implications. The improvement proposal should be implemented in any case if costs and emissions can be reduced (Implication 1). The measure should not be implemented if costs and emissions increase (Implication 2). The quadrants top left and bottom right represent a need for discussion within the company and must be decided on a situational basis (Implication 3). Often, the suggestions for improvement will be located in the upper left quadrant, when measures to improve the environmental footprint lead to an increase in costs (e.g. switching from petro-based packaging materials to sustainable degradable materials).

\section{Case Study (biotechnological glycoside production)}

The LCC and LCA was performed for a biotechnological glycoside production process of a cooperating company partner. The life cycle cost model was developed in an iterative process, with repeated consultations with the cooperation company on ongoing minor process changes, resource requirements and resource evaluation.

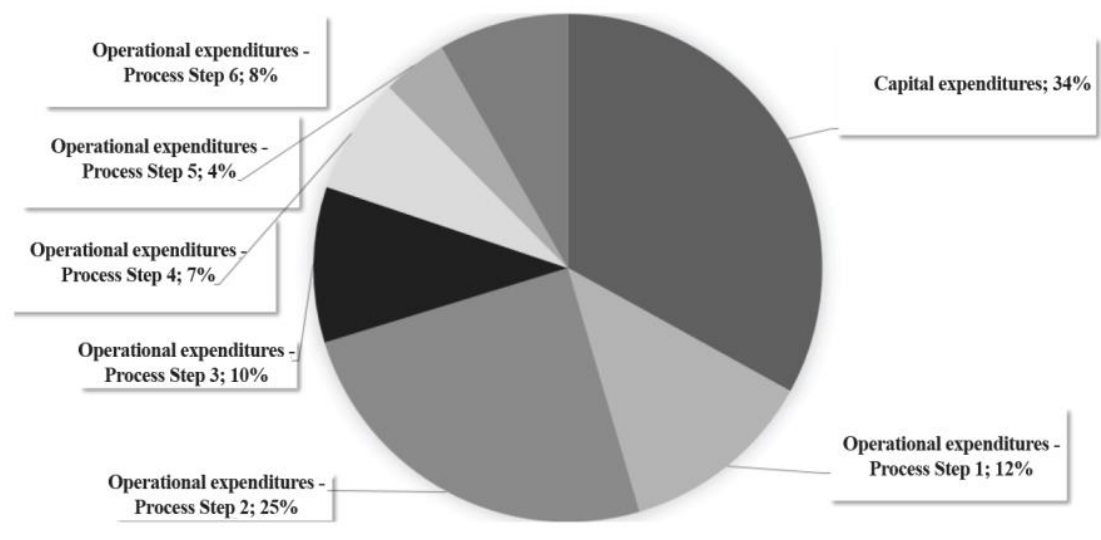

Fig. 4 Economic process hotspot analyses showcased for LCC analysis of a biotechnological glycoside production process

After modeling the data, they were evaluated. For this purpose, the operating expenses of all years were discounted to $t=0$ with the cost of equity of the company. The selffinanced capital expenditures were also evaluated. No aftercare costs are incurred in the company at the end of the product life cycle, as the product does not incur disposal costs. The costs for dismantling as well as disposal of the plant are negligible in the company. On the basis of this information, it was possible to obtain an initial overview (Figure 4) of where the highest expenses are to be expected, so that suggestions for process improvement can be made. LCA was as well conducted based on the same boundaries and inventory as used for LCC analysis. Within the process step with highest costs and environmental footprint impacts of single inventory items are presented as percentage share of total cost or environmental footprint (Figure 5). 


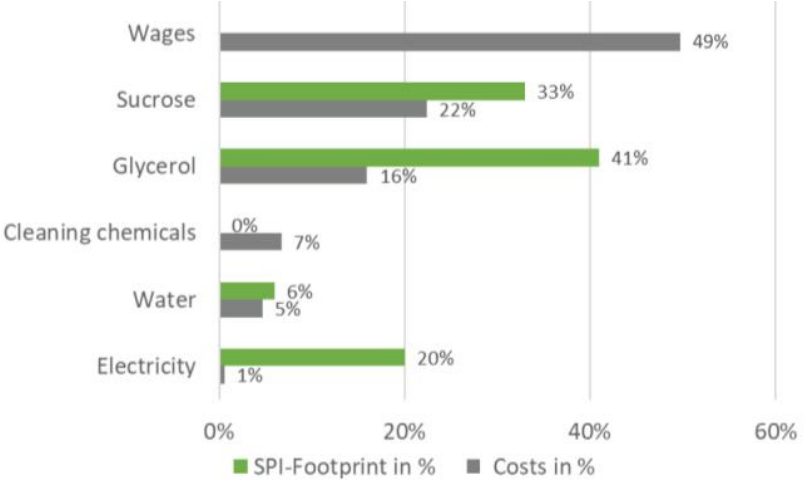

Fig. 5 Main contributors to economic and environmental burden of the biocatalytic synthesis unit operation in biotechnological glycoside production (biocatalyst fermentation was treated as separate process unit and is not included here)

From an economic point of view, the highest cost items are of particular interest. However, the evaluation of the optimization potentials was also carried out under environmental aspects, so that not only the effects of a cost optimization, but also a sustainable optimization was considered (Janz \& Westkämper 2007). For example, it was revealed that the electricity had previously been purchased from a fossil-fuel power generator. The environmental footprint was therefore high. The following example of visualizing combined economic and environmental evaluation results clearly shows that the optimization measure "switch to green electricity" has a low economic but high (positive) environmental impact.

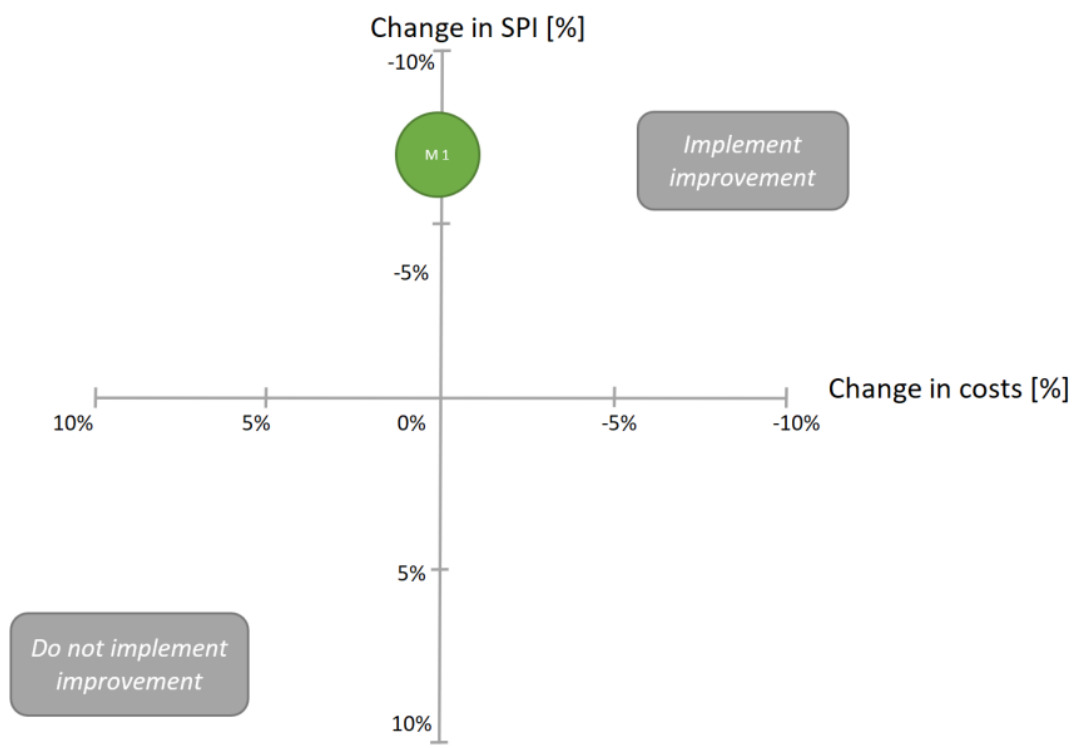

Fig. 6 Presentation of the change in costs and sustainable process index (SPI) for the optimization measure of electricity switching from conventional to sustainable supplier mix for the biocatalytic synthesis step in glycoside production. 
Figure 6 shows an application example for a recommendation to reduce the environmental footprint. Switching the electricity supply for the process from conventional electricity to green electricity results in a reduction of the overall environmental footprint of the hot spot process step "biocatalytic synthesis" by $7 \%$ (from $20 \%$ in the reference process to $13 \%$ in the process switched to green electricity). This measure is accompanied by higher electricity costs. Green electricity is $30 \%$ more expensive than conventional one in our example. When looking at electricity prices alone this might be interpreted as a too high increase to implement. However, a combined presentation of impact on total costs as well as total environmental burden makes clear, that increase in total cost by $0.2 \%$ is marginable and should be considered for implementation when aiming at more environmentally friendly processes.

For the application in companies, optimisation means that each improvement proposal, which was mentioned in an improvement plan, must be examined with regard to the change in the cost and environmental impact situation and it must be assessed individually for each measure whether it should be implemented or not. In practice, a representation method for suggested measures which allows easy visual capture of the impacts will be highly advantageous for this decision process.

\section{CONCLUSION}

This paper presents a procedure how to assist optimization of processes taking into account the environmental and economical perspective. The focus is on a practical approach to how technical improvement proposals can be presented. The 4-quadrant matrix can be used to show visually and transparently how changes in the process affect the environmental footprint as well as cost. The starting point is the original process, which represents the origin in the presented graph. The respective technically feasible changes are evaluated by the controlling department and the induced change in total footprint and cost is displayed in the diagram. This provides management with an easy to capture basis for deciding whether the proposed measures should be implemented in the company.

A theoretical limitation of the method can be seen in the nature of the SPI calculation method used for environmental impact evaluation. Although this has the advantage that a single value, namely an increase or decrease in overall environmental footprint represented as an area value, is calculated, a differentiation of impacts in single impact categories (such as climate change, eutrophication, water depletion etc.) is disregarded.

In the case of the LCC-model, the validity of future income and expenditure in particular causes problems. With an assumed long life cycle, the future figures are fraught with uncertainty. This affects the extrapolation with the existing indices. Furthermore, suitable indices do not exist for all cost types in order to make the price adjustments.

The practical limitations are that the information for the valuation of the individual measures is usually difficult to obtain. In the above mentioned project, for example, it became apparent that the primary data for cost and life cycle inventory could only be obtained with great difficulty and effort of industrial partners. A careful assessment of the data quality should therefore accompany impact evaluation and could in future be included in the here described method for presentation of economic and environmental optimization potential. 


\section{Acknowledgements}

The CARBAFIN project has received funding from the European Union's Horizon 2020 research and innovation program under grant agreement No 761030 (CARBAFIN). Results and statements presented in this paper reflect only the author's view, the Commission is not responsible for any use that may be made of the information the paper contains.

The authors also thank the company bitop AG, Dortmund (Germany) for good collaboration in the CARABFIN project and for providing primary company data for LCA and LCC analysis. In particular we thank Dr. Steven Koenig for his valuable engagement in process data recording and collection and gratefully acknowledge the support by Dr. Markus Neumann and Co-CEO Eva Galik.

\section{REFERENCES}

Anastas, P., \& Eghbali, N. (2020). Green Chemistry: Principles and Practise. Chemical Society Reviews, 39(1), 301-312. https://doi.org/10.1039/b918763b

Audsley, A., Alber, S., Clift, R., Cowell, S., Crettaz, P., Gaillard, G., Hausheer, J., Jolliet, O., Kleijn, R., Mortensen, B., Pearce, D., Roger, E., Teulon, H., Weidema, B., \& van Zeijts, H. (forthcoming), (1997). Harmonisation of Environmental Life Cycle Assessment for Agriculture, Final Report for Concerted Action AIR3-CT94-2028, 1-101. European Commission DG VI Agriculture.

Baum, H.-G., Coenenberg, A. G., \& Günther, T. (2006). Strategisches Controlling [Strategic Controlling]. 4th edition. Stuttgart: Poeschel Verlag.

Cavaignac, R. S., Ferreira, N. L., \& Guardani, R. (2021). Techno-economic and environmental process evaluation of biogas upgrading via amine scrubbing. Renewable Eergy, 171, 868-880. https://doi.org/10.1016/j.renene.2021. 02.097

Coenenberg, A. G., Fischer, M. T. \& Günther, T. (2016). Kostenrechnung und Kostenanalyse [Cost accounting and cost analysis]. 9th edition. Stuttgart: Schäfer-Poeschel Verlag.

Dascalu, C., Caraiani, C., \& Lungu, C. (2008). Eco-Cost Challenges for Environmental Protection. Journal of Environmental Protection and Ecology, 9(4), 925-939.

Ewert, R., \& Wagenhofer, A. (2014). Interne Unternehmensrechnung [Internal company accounting]. 8th edition, Berlin Heidelberg: Springer-Verlag.

Fazeni, K., Lindorfer, J., \& Prammer, H. (2014). Methodological advancement in Life Cycle Process Design: A preliminary outlook. Resources, Conservation and Recycling, 92, 66-77. https://doi.org/10.1016/j.resconrec. 2014.08.011

Fitzgerald, D. P., Hermann, J. W., Sandborn, P. A., Schmidt, L. C., \& Gogoll, T. H. (2005). Beyond tools: A design for environmental process. International Journal of Performability Engineering, 1(2), 105-120.

França, W. T., Barros, M. V., Salvador, R. de Francisco A. C., Moreira, M. T. \& Piekarski, C. M. (2021). Integrating life cycle assessment and life cycle cost: a review of environmental-economic studies. International Journal of Life Cycle Assessment, 26, 244-274. https://doi.org/10.1007/s11367-020-01857-y

ISO 14040 (2006). Environmental management-life cycle assessment-principles and framework. Geneva, Switzerland: International Organization for Standardization.

ISO 14044 (2006). Environmental management-life cycle assessment-requirement and guidelines. Geneva, Switzerland: International Organization for Standardization

Janz, D., \& Westkämper, E. (2007). Design to life cycle by value-oriented life cycle costing. Advances in Life Cycle Engineering for Sustainable Manufacturing Businesses. Proceedings of the 14th CIRP Conference on Life Cycle Engineering, 461-466. https://doi.org/10.1007/978-1-84628-935-4_80

Keoleian, G. A., \& Menerey, D. (2012). Sustainable Development by Design: Review of Life Cycle Design and Related Approaches. Air \& Waste, 44(5), 645-668. https://doi.org/10.1080/1073161X.1994.10467269

Kumar, B., \& Verma, P. (2021). Life cycle assessment: Blazing a trail for bioresources management. Energy Conversion and Management, 10. https://doi.org/10.1016/j.ecmx.2020.100063

Luthin, A., Backes, J., \& Traverso, M. (2021). A framework to identify environmental-economic trade-offs by combining life cycle assessment and life cycle costing - A case study of aluminium production. Journal of Cleaner Production, 321, 1-17. https://doi.org/10.1016/j.jclepro.2021.128902

Markowitz, H. (1952). Portfolio Selection. Journal of Finance, 7, 77-91. https://doi.org/10.1111/j.1540-6261.1952. tb01525.x

Moretti, C., Hamelin, L., Jakobsen, L. G., Junginger, M. H., Steingrimsdottir, M. M., Hoibye, L., \& Shen, L. (2021). Cradle-to-grave life cycle assessment of single-use cups made from PLA, PP and PET. Resources, Conservation and Recycling, 169. https://doi.org/10.1016/j.resconrec.2021.105508 
Narodoslawsky, M., \& Krotscheck, C. (1995). The sustainable process index (SPI): Evaluating processes according to environmental compatibility. Journal of Hazardous Materials, $41(2+3), 83$.

Narodoslawsky, M., \& Stoeglehner, G. (2010). Planning for Local and Regional Energy Strategies with the Ecological Footprint. Journal of Environmental Policy \& Planning 12(4), 363-379.

Neugebauer, G., Kretschmer, F., Kollmann, R., Narodoslawsky, M., Ertl, T., \& Stoeglehner, G. (2015). Mapping thermal energy resource potentials from wastewater treatment plants. Sustainability (Switzerland), 7(10), 12.988-13.010. https://doi.org/10.3390/su71012988

Obrecht, P. T., Röck, M., Hoxha, E., \& Passer, A. (2020). BIM and LCA Integration: A Systematic Literature Review. Sustainability, 12, 5534. https://doi.org/10.3390/su12145534

Ögmundarson, O., Sukumara, S., Herrgard, M. J., \& Fantke, P. (2020). Combining Environmental and Economic Performance for Bioprocess Optimization. Trends in Biotechnology, 38(11), 1203-1214. https://doi.org/10.1016/ j.tibtech.2020.04.011

Ouattara, A., Pibouleau. L, Azzaro-Pantel, C., Domenech, S., Baudet, P., \& Yao, B. (2012). Economic and environmental strategies for process design. Computers \& Chemical Engineering, 36, 174-188. https://doi.org/10.1016/j.compchemeng.2011.09.016

Patel, M., Zhang, X., \& Kumar, A. (2015). Techno-economic and life cycle assessment on lignocellulosic biomass thermochemical conversion technologies: A review. Renewable and Sustainable Energy Reviews, 53, 1486-1499. https://doi.org/10.1016/j.rser.2015.09.070

Pesonen, H.-L., \& Horn, S. (2013). Evaluating the Sustainability SWOT as a streamlined tool for life cycle sustainability assessment. International Journal of Life Cycle Assessment, 18(9), 1780-1792. https://doi.org/10. 1007/s11367-012-0456-1

Ribeiro, I., Pecas, P., Silva, A., \& Henriques, E. (2008). Life cycle engineering methodology applied to material selection, a fender case study. Journal of Cleaner Production, 16(17), 1887-1899. https://doi.org/10.1016/j. jclepro.2008.01.002

Shahzad, K., Kollmann, R., Maier, S., \& Narodoslawsky, M. (2014). SPIonWEB - Ecological Process Evaluation with the Sustainable Process Index (SPI). Computer Aided Chemical Engineering, 33, 487-492. https://doi.org/10.1016/B978-0-444-63456-6.50082-X

Simoes, C. L., de Sá Figueiredo, R., Ribeiro, C. J., Bernardo, P., Pontes, A. J., \& Bernardo, C. A. (2016). Environmental and economic performance of a car component: assessing new materials, processes and designs. Journal of Cleaner Production, 118, 105-117. https://doi.org/10.1016/j.jclepro.2015.12.101

Söllner, F. (1998). Konflikt zwischen Geld und Natur? Zum Verhältnis von monetärem Sektor und Nachhaltigkeit Conflict between money and nature?. [On the relationship between the monetary sector and sustainability]. Ökologisches Wirtschaften, 6, 20-22.

SPIonWeb (Sustainable Process Index on Web), Retrieved from: http://spionweb.tugraz.at, 2013 - 2019, Accessed on: 23 April 2021.

STRATECO OG, Retrieved from: https://www.strat.eco/en, Accessed on 23 April 2021.

UNEP/SETAC (2009), Guidelines for social life cycle assessment of products. United Nations Environment Programme (UNEP) and Society of Environmental Toxicology and Chemistry (SETAC), Belgium

Valdivia, S., Ugaya, C. M. L., Hildenbrand, J., Traverso, M., Mazijn, B, Sonnemann, G. A. (2013). UNEP/SETAC approach towards a life cycle sustainability assessment — our contribution to Rio+20. International Journal of life cycle assessment 18, 1673-1685. https://doi.org/10.1007/s11367-012-0529-1

Vaskan, P., Pachon, E. R., \& Gnansounou, E. (2017). Techno-economic and life-cycle assessments of biorefineries based on palm empty fruit bunches in Brazil. Journal of Cleaner Production, 172, 3655-3668. https://doi.org/10. 1016/j.jclepro.2017.07.218

Yin, R. K. (2011). Applications of Case Study Research. 3rd edition. North America: Sage Publishing.

Yin, R. K. (2017). Case Study Research and Applications: Design and Methods. 6th edition. North America: Sage Publishing.

Zehbold, C. (1996). Lebenszykluskostenrechnung [Life cycle costing]. Wiesbaden: Springer Verlag Fachmedien.

\section{INTERNO IZVEŠTAVANJE O MERAMA ZA OPTIMIZACIJU PROCESA: KOMBINACIJA EKONOMSKIH I EKOLOŠKIH ASPEKATA}

Optimizacija troškova je deo svakodnevnog poslovanja kompanije. Razvijeni su brojni instrument ii metodi za izračunavanje potencijalnih ušteda i njihovo saopštavanje donosiocima odluka. U budućnosti, kako bi kompanije poslovale održivije, neophodno je da se mere optimizacije sagledavaju sa ekonomskog 
is a ekološkog stanovišta. Ovaj rad predlaže da se izveštaji dopunjavaju matricom koja ekonomske i ekološke uticaje stavlja nasuprot pojedinačnih mera optimizacije. Ovakav način izveštavanja bi trebalo da pomogne donosiocima odluka u odabiru mera optimizacije, uzimajući u obzir ekomonske i ekološke aspekte. Kao studija slučaja uzeta je procena LCA i LCC-bazirane evaluacije biotehnološkog procesa za proizvodnju glikozida. Pokazan je primer prezentacije uticaja prelaska na održivi električni miks.

Ključne reči: izveštavanje, poboljšanje procesa, LCA, LCC, LCA/LCC kombinacija, ekonomske i ekološke performanse, održivost, CARBAFIN 